\title{
PROFESSIONS AND THE SOCIAL ORDER: SOME LESSONS FROM BURKINA
} FASO?

Natéwindé Sawadogo, University of Ouaga II, Burkina Faso, natewinde.sawadogo@yahoo.fr Robert Dingwall, Dingwall Enterprises Ltd and Nottingham Trent University, United Kingdom, robert.dingwall@ntlworld.com

\begin{abstract}
The study of professions has been dominated by Anglo-American models, with their focus on a small group of legally-licensed occupations. The field has recently shifted, mainly through studies of European experience, to a wider examination of the social management of expert workers. Very little has been written about developments in Africa and their implications for the way in which we might think about professions. This paper presents a case study of the role and practices of the medical profession in Burkina Faso, which has a relatively open market for the supply of healing services and limited regulation of the suppliers, whether physicians or traditional practitioners. The study returns to classic questions about the extent to which practice is shaped by the nature of occupational niches within the division of labour or to the development of a distinctive moral character among the workers within that niche?
\end{abstract}

Keywords: self-interest, public interest, professions in Africa 


\section{INTRODUCTION}

It has long been observed that the study of professions has been dominated by AngloAmerican models, with their focus on a small group of legally-licensed occupations (e.g. Rueschemeyer 1983). Attention has recently shifted, mainly through studies of European experience, to a wider examination of the social management of expert workers (Svensson and Evetts 2010. See also Gorman and Sandefur 2011). Very little has been written about developments in Africa and their implications for the way in which we might think about professions. This paper uses a case study of the medical profession in Burkina Faso to examine the constitution of a niche within the division of labour and its implications for the moral practice of work within it. Is 'professional' behaviour a property of the niche or of the actors within it? The first section introduces the conceptual framework and methods of the study. The second, third and fourth sections describe the development of the niche for medical practice in Burkina Faso through the demand for, and supply of, legal, economic and cultural resources. The fifth section examines the implications of this commercially structured situation for the practice of medicine in Burkina Faso, and the wider lessons for the sociology of the professions.

\section{THE SYSTEM OF PROFESSIONS: STRUCTURE AND PRACTICE}

Early writings about the professions noted their emergence as a partial solution to the problems of trust created by the division of labour in the course of social and economic modernization. This created asymmetries of knowledge and expertise between members of society that could be highly consequential for individual and collective futures (Dingwall 1995; 1999). How could experts be prevented from exploiting or abusing their structurallyadvantaged positions or monopolies? Could this outcome be achieved simply by the 
evolutionary processes of the division of labour, and the nature of the occupational niches that they generated, or did it require special forms of governance?

Adam Smith (1976), for example, was generally critical of guilds as a source of monopoly and market closure. Nevertheless, he saw the problems of trust, and consequent market failure, as sufficient justification for self-regulating professional associations in these areas. His position was echoed by Durkheim (1960) in Division of Labour. This book proposes a guild-like system of occupational associations as a way to limit potential abuses in unrestrained markets. Membership would be a source of moral constraint on the unbridled exercise of self-interest. Durkheim (1992) developed this theme, with a larger role for the state in supervising the system, in later lectures, published as Professional Ethics and Civic Morals. These lectures gave more emphasis to the internalization of a sense of civic obligation through the wider educational system and specific occupational or professional training. Professionals, and other workers, would literally find it unthinkable to abuse their market advantages. This line of argument was continued by Parsons $(1939 ; 1951)$, discussing altruism as a restraint on self-interest in both professional and business occupations that contributed to the successful functioning of modern societies.

In parallel, however, other sociologists continued to explore the structural questions about the division of labour established by Smith, and later by Herbert Spencer, in their evolutionary or ecological approaches (Dingwall 2016; Dingwall and King 1995). These focussed on understanding the dynamics of the process, the niches being created by social, economic and technological change, and the various attempts at colonizing them by different occupational groups (Hughes 1984; Abbott 1988). This approach tended to flatten the moral distinctions between professions and other occupations, who were all seen as self-interested and strategic 
actors. In some hands (e.g. Freidson 1970; Johnson 1972; Larson 1977), this developed into a critique of professions as monopolies or cartels, using their expertise to capture the state and extract economic rents or status advantages from their position. While there were always empirical problems with this analysis (Rueschemeyer 1986; Johnson 1995; Light 1995; Dingwall 1995), it came to dominate throughout the 1980s and 1990s. It is still influential, although some advocates adopted a more nuanced view in later work (Dingwall 2006). The state was reintroduced as an independent actor such that professional monopolies were supplied to further state interests rather than simply being demanded to further occupational interests. The understanding of state interests varied from a concern to promote efficiency and effectiveness in publicly-funded ventures through a desire to survey and manage populations to an attempt to manage overload by dispersing sites of governance and citizen services. Professions also came to be seen as potential sources of moral resistance to inhumane or oppressive behaviour by state actors. This is, for example, a theme in Liu's (2017) analysis of the legal profession in contemporary China, which examines its role as a mediator between state and market and its activism in relation to human rights.

One of the consistent problems with this body of work has, though, been its limited empirical base. As Liu (2017: 213) notes: 'Despite the fast-growing number of doctors, lawyers, engineers, economists, and many other professionals in developing countries, little effort has been made to theorize the relationship between professions and development in the Global South'. An African case study allows us to examine a situation where a medical profession based on allopathic principles has not, or not yet, achieved legal and cultural hegemony. Burkina Faso has a relatively open market for the supply of healing services and limited regulation of the suppliers, whether trained in the European tradition of allopathic (scientific) medicine or the traditional practices of the various communities to be found within the 
country. Within such a context, it is easier to adopt the principle of symmetry derived from science and technology studies and to insist that all healing workers should be treated within the same analytic frame (Bloor 1991). A study of their relations with patients, states and markets should help us to disentangle some of the key propositions of the sociology of professions about the balance between altruism and self-interest in the practice of their craft. How does the ecological context interact with the normative stances traditionally considered to be distinctive to professional work? Is 'professional' behaviour a property of the niche or of the actors within it?

We have, then, competing accounts of professional practice. Are disinterestedness and altruism the necessary consequence of internalized social structures, expressed in the talk and actions of licensed practitioners? Unlicensed practitioners are not able to behave in this way because they have not internalized the same structural model. They are positioned in a commercial sector where individual self-interest is said to be the internalized disposition. Traditional healers might be thought to serve their clients in their own interest, where medical doctors prioritize the interests of their clients, even in private practice. As Sciulli (2009: 200) notes, though, this may not adequately characterize practice in the commercial sector: "No one is prevented, certainly, from acting altruistically or selflessly". The alternative is to see the expression of professional values as something that may characterize any occupation as part of its claims to be recognized as the legitimate owner of a bundle of tasks and to demarcate an ecological niche within the division of labour. The open market for health care in Burkina Faso offers a good case to test these rival accounts.

\section{Research Design and Methods}


This study was designed to examine the ecology of healing work in Burkina Faso, a former French colony in West Africa. Rather than beginning with the prior categories of an official map of the division of labour, we chose to start from the work of healing, to ask who did it and how they were organized in more or less systematic ways. In doing so, we were adopting an approach outlined by Hughes (1984) and developed further by Freidson (1978; 1994. See also Dingwall 1983). This decouples the universe of work and the classification of occupations imposed upon it. In effect, Freidson challenged researchers to think about the principles upon which a taxonomy of occupations might be based. For him the key dimensions were the relationship between the tasks and the legitimate market economy: is the work paid or unpaid? Recognized as lawful or banned as criminal? Although Freidson places most emphasis on the economic and legal dimensions that lead an occupation to be officially recognized, it is clear from his discussion that there are potentially others. These certainly include cultural and symbolic dimensions: what work does a society consider appropriate to incorporate within the market? What rewards are offered other than the purely monetary, whether within or outside market transactions? These are clarified in Bourdieu's influential discussion of varieties of capital (Bourdieu 1986: 243): economic which "refers to money or liquid assets"; social which denotes the possession of a "durable network of more or less institutionalized relationships of mutual acquaintance and recognition"; cultural which is acquired through the educational system; and symbolic which "denotes reputation and professional prestige'. ${ }^{1}$

Data were gathered from the Archives de la Défense, in France; Archives Nationales $d u$ Senegal, in Dakar, and Archives Nationales du Burkina Faso, in Ouagadougou; from government documents on development and health policy; from court records of medical malpractice cases; and from legislation. In total, seventy-five interviews were carried out with 
representatives of various stakeholders in health policy - government and civil service, NGOs, associations of both licensed medical practitioners and traditional healers, supplemented by observations of practice in both 'traditional' and 'modern' environments. The analysis mixed inductive and deductive elements with data coding derived partly from an inspection of the data and partly from specific questions derived from a review of the published literature. The data discussed here come from those codes dealing with the relationships between different types of healer and their patients, with the impact of legal frameworks on the practice of healing, and on the jurisdictional strategies pursued by healers. Our focus is on how various influences combine and interact to shape the niche occupied by allopathic doctors in Burkina and Faso and to promote, or discourage, behaviour that is professional in terms of its ethics, morality or integrity.

\section{THE LEGAL ORDER OF HEALTH CARE IN BURKINA FASO}

Freidson (1978) emphasized the legal and economic dimensions of a taxonomy of occupations. From independence in 1960 until the end of the 1980s, the official market for healing work in Burkina Faso was defined and dominated by the state, through legal acts. (In practice, most citizens actually used traditional healers operating in an informal market, whether as substitutes or complements for licensed allopathic medical practitioners.) The state derived political legitimacy from the free or heavily-subsidised provision of social services, including health care (World Bank 1990). While the state had assumed a legal responsibility to provide medications, in reality individuals still needed to buy them privately (Kabore 2002). The role of the state declined through a number of coups d'état in the 1980s, which weakened the internal economy. This deterioration was initially covered by external borrowing, but failure to meet debt repayments led the country into a Structural Adjustment Programme (SAP) from 1991. As is common with such programmes, economic reforms led 
to significant transfers of functions, including health, from the state to the market. State expenditure on health care fell from 7 per cent of the national budget in 1991 to 4 per cent in 1995 (Sawadogo 2012).

Private provision of allopathic medicine had always existed in Burkina Faso. First practiced unofficially by French expatriates, it boomed after the 1991 market reforms, which supplied a legal framework for the private provision of health services. Medical practice was liberalized: different areas of professional practice were defined in the Public Health Code by law no.23/94/ADP of 19 May 1994. Hospital law no.034/98/AN/ of May 1998 organized the health system by defining the different categories of health services. Decree no.398/PRES/PM/MS of 19 July 2005, complemented respectively by the inter-ministry and ministerial by-laws no.2006/MS/MCPEA/MFB of 16 June 2006, no.200-060/MS/CAB, defined the conditions of professional licensing, and of the opening and operation of private health care centres.

The emphasis on constructing a 'modern' state in the early years after independence meant that traditional medicine was relatively neglected in legal terms. Order no.70-68 bis/PRES/MSP/AS of December 1970 formally tolerated the practice of traditional medicine (Bognounou and Guinko 2005:33). This space was enlarged in 1994 by law no.23/94/ADP on the Public Health Code which "recognises Traditional Medicine and Traditional Pharmacopeia as one of the components of the national health system" (Bognounou and Guinko 2005:34). Current estimates are that more than 80 per cent of the population uses traditional medicine at some time. In 2010 it was thought that there were more than 30.000 traditional healers in the whole country, including at least 600 in Ouagadougou, the capital. Marabouts, Muslim holy men, have been influential in the supply of healing services since 
the pre-colonial period (Sawadogo 2012). Soubeiga (1999:111) also notes that "Apart from their traditional activities of evangelization, one of the common characteristics of Christian churches of different denominations established in Burkina Faso is that they appear more and more as places of care of illness". Moreover, there is a sizeable but undocumented market in informal sales of prescription drugs in both rural and urban areas.

The private provision of health services is relatively unregulated. They are legally considered to be commercial enterprises and treated as such by the tax system. Pricing and prescriptions are not controlled and there are no quality standards regarding facilities, equipment and personnel (Ouédraogo, 2010). The involvement of private actors in development aid, and their strong control of funding, displaced the state as a regulator in the field of health care, and then institutionalized profit motives as acceptable and even desirable. The weakening of state power created opportunities for citizens to engage with private agents to provide means of payment and actual services in parallel with, or replacing, those of the state.

If we compare Burkina Faso with the countries traditionally studied by the sociology of the professions, we can, then, see that healing work is only loosely classified and regulated by the state through the supply of a legal order that might define officially-recognized niches. No particular group of providers has a clear structural advantage in the provision of services: there are few constraints on the supply of medicinal products and no notion of the unlicensed practice of medicine. This is a context within which providers have wide scope for selforganization and self-regulation, should they see any collective advantage in doing so. There are few barriers to entry, other than those of building a reputation. The legal order does not specifically promote professional integrity. 


\section{THE ECONOMIC ORDER OF HEALTH CARE IN BURKINA FASO}

The shift from public to commercial models in the supply of health care redefined the economic dimension of occupational niches in two ways. One was the emergence of third party payers and the other was the reconstitution of patients as consumers rather than beneficiaries. This, however, only affected the small proportion of the population formally employed within the officially-recognized part of the economy. They had been covered by a social security system developed between 1970 and 1983 through legal instruments like Law $\mathrm{n}^{\circ} 13 / 72$ AN of 28/12/1972, which created the National Social Security Fund (Caisse Nationale de Sécurité Sociale) providing Family Benefits (Prestations Familiales), benefits for Work Accidents and Occupational Diseases (Accidents du Travail et Maladies Professionnelles-AT \& MP) and Old Age Insurances (Assurances Vieillesse-AV). As of 2001, only 11 per cent of the population was covered by this mechanism, meaning that, like most neighbouring countries in Sub-Saharan Africa, 90 per cent of the population, working in informal sectors, were excluded (Bationo and Ouédraogo 2012; Ouédraogo 2012). The SAP moved the formally employed part of the population towards the position of the informally employed, with liability to pay individually for health care.

However the state's retreat from the funding of health care did not lead to a general increase in the power of consumers to influence the occupational niches and the actions of those claiming them. The majority of the population cannot afford health care from their own resources. Typically, costs are covered by informal means such as loans, dissolution of savings or the selling of essential resources (Bationo and Ouédraogo 2012). Initially, the state sought to assist by promoting cheaper forms of primary care, but it was under strong pressure to abandon any role in social protection in order to achieve economic reform (Zagré, 1994). Like other West African countries, Burkina Faso adopted the framework of the Bamako 
Initiative (Ridde 2007). In the name of involving communities in their own health care, while relieving the state from the burden of social expenditures, this introduced user fees and costrecovery mechanisms together with responsibilities for those communities to manage existing health facilities. However, social change in rural areas, and the consequences of privatization, had impoverished large sections of the population, who were excluded from access to this official system of care.

During the 1990s, community health mutual insurance schemes (mutuelles de santé) emerged as local responses to the problems of access and quality of health care. These take a variety of forms including mutual health insurance companies, assistance societies, insurance societies, specific prepayment schemes, mutual solidarity funds, professional mutual associations, and solidarity banks. Despite this diversity they share a common aim to assist poor and vulnerable groups to access adequate health care services. In theory, these schemes could potentially reach into the large informal workforce but in practice less than 1 per cent are covered. They have increased from 6 organizations in 1997 to 146 in 2005 (Ouédraogo 2012). Since 2000, the government, with the help of the International Labour Organization, has tried to support local mutual schemes to develop a network offering national coverage. ${ }^{2}$ Decree no. $2008-736$ of Feb 2009 established a Committee (Comité de Pilotage) to develop a National Health Insurance System like that in Ghana. The Universal Health Insurance system (Assurance Maladie Universelle-AMU), completed in 2015, rests on the foundation of the mutuelles de santé . There are also private commercial insurances (including SONAR, FONCIAS, UAB, GA, Colina Assurance), but they only cover a tiny privileged minority (Ouédraogo 2012).

In structural terms, the position of people in need of health care in Burkina Faso has shifted from one where a minority were the beneficiaries of state-funded access to state organizations 
providing allopathic treatment, while most were purchasing such care as they could afford in a market largely served by traditional healers. A small elite accessed allopathic medicine through a tiny private sector. It is not clear that the mutual insurance model has actually much enlarged the proportion of the population able to access allopathic services but it has shifted the costs of doing so. While rhetorically recasting patients as consumers, active agents in their choice of care, rather than beneficiaries, passive recipients of state provision, it has not necessarily altered their relationship with providers. For the social groups within mutual or private insurance schemes, most costs are still met by a third party whose decisions set the organizational and resource contexts within which their recognized providers operate. For the remainder of the population, out of pocket payments to the provider of choice continue to dominate. There are, then, very few sources of economic pressure on providers that might shape their occupational niche and what is considered to be appropriate behaviour within it.

\section{The rise of private clinical practice}

The withdrawal of the state from health care funding has been paralleled by its withdrawal from direct provision. Private medical practice existed on a small scale in colonial times, mainly carried out by French military doctors alongside their official duties (Sawadogo 2012). After independence, it remained a low-level activity until the 1980s (Haute-Volta 1986). In 1991, there were 58 centres providing private health services. By 2009, however, this had increased to 380: about half of these were in Ouagadougou and a quarter in BoboDioulasso, the second biggest city (Ouédraogo 2010). The most urbanized part of the country, the central region, had at least 317 centres identified by the Ministry of Health, of which 118 were pharmacies and 11 biomedical laboratories. The rest were health care centres. More than two thirds of these were private, about half being for-profit; 97 per cent of the private health centres were in the city. (Ministère de la Santé, 2010). Growth has since continued 
more slowly but there were 407 private health centres in 2014, with 84 explicitly for-profit. (Ministère de la Santé 2015; Ouédraogo, 2010).

The changing framework for the funding and provision of allopathic health care has, then created a context for medical practice that is somewhat more directly commercial, at least for those who use it. There is a chain of payment from consumers to third party payers who then contract with private providers or reimburse users for some proportion of their out of pocket expenses. Alongside this, as ever, is a large volume of traditional medicine that has always had an immediate economic connection to its users. While the healing work of Burkina Faso remains little changed, the institutional map laid over it has shifted considerably since the 1980s. Allopathic medicine, in particular, is no longer delivered, to those who choose it, by a benevolent state through its employees. The ecological niche occupied by medical practitioners educated in a Western scientific tradition looks very different, although that occupied by traditional practitioners is little changed. What has this meant for practice?

\section{ECONOMIC CAPITAL VS SYMBOLIC CAPITAL: DOCTORS IN AN OPEN MARKET FOR HEALTH CARE}

In the immediate post-independence period, the medical profession had allied with the state to protect and expand its jurisdiction. The traditional sector was not directly attacked but was expected to decline as a better-educated population gained access to allopathic medicine. The 1970 legislation that had delegated to the regulatory bodies governing the medical profession powers to promote traditional medicine only began to be implemented in 2006 (Ministère de la Santé 2006) ${ }^{3}$. The commitment to state provision had created a market shelter, which also provided a base from which to offer private services to a small elite patient group that shared the culture and values of the physicians. The medical profession traded on symbolic capital - 
elite culture - to derive economic capital - state employment or patient fees. The state's withdrawal from financing and provision undermined this shelter. In an open market, the doctors were competing with traditional practitioners, who derived their symbolic capital from their deep historical roots in the mass of the population, particularly in relation to their various ethnic and religious affiliations. The medical profession responded in three ways to protect its interests: it used its position in the state bureaucracy to maintain professional market regulation; it enforced these regulations against competing healers; and it promoted profit-seeking relationships with patients.

\section{The Crisis of the State and the Rise of Professional Control of the Health Care Field}

The autocratic character of government in Burkina Faso means it that it does not depend heavily on citizen goodwill as its source of sovereign power. This is not inconsistent with regular elections (Ottaway, 2003; Hilgers and Mazzocchetti , 2010; Politique Africaine, 2006). As with all patrimonial power, the protection of the ruling elite, rather than that of the majority of the population, is the most important goal. On the other hand, the government's power over the health professions is weaker than that over the general population. The state collects taxes from health professionals; it needs health experts to design its regulations; and its leaders are aware that an alliance between the health professions and the wider population is a potential threat. As has been pointed out in developed countries, there are interdependencies between states and professions (Rueschmeyer 1986; Halliday 1987; Johnson et al. 1995). Since the colonial period, the Burkinabé medical profession has also become deeply embedded in the state's administrative and technical institutions. However, this has brought them few material rewards, relative to those available to the political elite, despite being among the best-educated groups in the country. While the medical profession may have been privileged in some respects by its sheltered niche, it was not able to extract an 
economic rent. The annual salary of a General Practitioner, for example, including all allowances and benefits, is less than 600 USD, equivalent to just one of the allowances ${ }^{4}$ paid to judges, who only require a Masters degree for their appointment (Bocoum et al. 2009) ${ }^{5}$. In one of their interviews a rural doctor compares his position to a tax inspector:

...he is in (salary grade) A1 as a doctor, that's already abnormal. We should not be in the same category. His basic education is a master's degree, we have a doctorate and we are on the same footing. Which demotivates people from the start. When you see that you leave the college after 8-9 years of study and you come to see you have the same salary as someone who has only done 4 years, you are demotivated. (Bocoum et al 2009: 32)

Contrary to the assumptions of the economic reformers, the withdrawal of the state from health care provision actually led to greater market control by the medical profession and a more substantial attempt to establish an effective monopoly. The profession attacked traditional healers with greater vigour, while using the decline of state oversight to direct and charge patients in self-interested ways (Code Public et Administratif 2000). In one of our interviews, a doctor explained that, apart from outpatient consultations which are fixed, the aim is to keep patients in hospital as long as possible. Each visit by a doctor to a hospitalized patient earns 6 USD; there are also daily charges for nursing care and the occupancy of the room. Medications provided by the clinic - rather than brought in - must be paid for on the day of discharge.

\section{Symbolic Capital and Interprofessional relationships}

The medical profession's symbolic capital declined rapidly during the political turbulence of the 1980 s and was not restored by the market reforms. At the time of independence, 
symbolic capital was derived largely from the profession's association with the colonial regime as a form of imagined modernity. The small educated elite that established the new state identified with this future and saw doctors as agents for bringing it into being: indeed, the few African doctors in the country had often been involved in the liberation struggle and were as much involved in politics as in medical practice (Ouédraogo 2010). However, the profession was unable to develop cultural capital that would sustain the symbolic capital. Its knowledge base was derived from the problems of interest to the colonial power and was not renewed through a research system that might have connected to the problems experienced by the mass of the population. The French doctors who had served the colonial elite largely remained in place serving the new national elite until the end of the 1970s, when the practice of non-citizens was restricted. They were not fully replaced by African doctors until the 1990s.

The medical profession supplied the allopathic medicine demanded by the educated elite but did not develop its social capital by widening its networks through engagement with the culture of other groups within the society. The professional niche was, then, quite fragile and heavily dependent upon the support supplied by a particular elite group. Holders of medical degrees had a nominal legal monopoly of practice under a colonial decree of 1952, which was not replaced until 1970. There was some intermittent persecution of traditional healers, but there was little direct competition: each occupational group served a distinct market sector.

Under the revolutionary regime (1983-1990), these boundaries were dismantled. In some respects, this can be compared with the Jacksonian abolition of professional guilds in the US during the 1830s (Kett 1968). Allopathic medicine was identified with the elite that had been overthrown and the regime effectively levelled the playing field to allow all kinds of healers 
to flourish. The result was a significant shift in the balance of power between the occupations supplying healing services. In particular, pharmacists who were more numerous and dispersed across the country were able to ally with the regime and to take over key positions in the health ministry. The pharmacists had established a more pragmatic relationship with many traditional healers, as suppliers of the local pharmacopoeia alongside officiallyrecognized medications, when available (cf. Patterson 2015 on neighbouring Senegal). They were able to expand their occupational niche by drawing on the social and cultural capital they had acquired through their deeper engagement with the population and their alliances with traditional practitioners.

As the 1991 market reforms were extended to health care, the state withdrew from a direct role in the governance of the medical profession, establishing professional Orders, selfgoverning associations with legal powers to regulate practice. These were designed on French models: in practice, much of the legal framework for health care still has its roots in colonialera decrees, which have just been cut and pasted into the new statutes. The implementation and operation of the Orders has had limited support from the profession, because of concerns about the ways in which this might affect their private interests. They have concentrated on those areas where there is agreement, like attacks on traditional practitioners, restraints on price competition for patients, and controls on referrals. Partly in response, traditional healers have been forming their own associations to defend their sphere of work and to set standards for practice. These have, for example, made an important contribution to enrolling traditional healers in networks for the identification of people who may have HIV/AIDS and referring them to treatment centres. 
Since independence, then, the niche created for the Burkinabé medical profession by interactions between the occupational group, the state and the market has changed in significant ways. The close integration with the immediate post-independence state elite, based on shared symbolic capital has given way to a more distant relationship, where the profession is simply one among a group of competitors in a relatively open market. There is a sense that the state really does not care about the integrity of the medical profession:

Those who work in the business sector are better paid because people think they are taking risks. The judges are well paid because that we think that justice is independent, so we must pay them so that they are not tempted to be corrupt. But none of these people can save another's life. It's only the doctor who can save someone's life. I think doctors ought to be better paid because they take more risk. (Bocoum et al 2009: 32)

The profession still enjoys some social and legal privileges, and a certain amount of symbolic capital through its international connections to development agencies and elements of the national elite. However, the result has been a closing of professional ranks to defend the niche through recognizably monopolistic practices rather than to enlarge it by a more expansive engagement with the society as a whole.

\section{The Commercialization of Doctor-Patient Relationships}

The lack of state oversight leaves the medical profession free to deal with its patients in ways that maximize its ability to accumulate economic capital within its niche. This involves a variety of behaviours from manipulating the boundary between public and private provision to outright fraud. Although the latter is rare, there are cases where doctors have directly embezzled public funds or collaborated with pharmacists to generate bogus prescriptions, with the reimbursements split between them. 
More commonly, physicians exploit the interactions between private and public provision to their own advantage. Officially, private health centres are supposed to be professionally-led, but in practice the medical leadership is often a front for business interests, which have supplied the capital. One of our informants explained: 'According to the regulations, if you are not a doctor you cannot open a clinic. So there are dummies, because doctors do not always have the necessary funds for this; but it is not to be spoken out officially.' Stateemployed doctors are theoretically forbidden from engaging in private practice - but many do so, as was the case in the colonial period. If they do not, they are quite likely to receive referral fees for directing patients from public to private provision. As one general practitioner told us:

Even for complementary laboratory tests there are some who openly tell the patient to go to a given place. Yes! Last time I received a patient who told me that the doctor told him to go and do the tests at a specific place; that if he goes somewhere else he will not examine the results; I advised him to go and see another specialist.

This is sustained by the manipulation of appointment systems and access to equipment. By limiting the number of appointments available in a public clinic, long delays for elective treatment can be induced and empty beds created because of the slow throughput: ' $\ldots$ this is common. You go to the hospital, you are given an appointment within two to three months, especially in a specialty where there is only one practitioner. You are obliged to ask him/her in which clinic you can see him.' These encourage patients towards the private sector, particularly for access to specialists. If hospital admission is required, the private sector can then take up the vacant beds, blocking them for other possible uses. (The private sector offers little provision for in-patient treatment). Public equipment may be deliberately disabled so that patients can only get access through a private centre. Over-treatment is common with 
lengthy in-patient stays and collusion with pharmacists to order drugs that are only available privately, leading public hospitals to underestimate demand and to run short because supplies have not been purchased: 'It's simple: those who own the clinics work at the hospital; those who work in the clinics work at the hospital. It is the same people so they do not complain!'

These practices go unchallenged because other groups are co-opted to support them. The small-scale organization of private health centres limits the opportunities for other recognized health workers to share in the benefits of part-time employment there. However, means are found to compensate them for such tasks as ensuring that defective public equipment is not speedily repaired. Medical students are employed in the private health centres, although they are not authorised to work for remuneration. These other occupational groups acquire an interest in the status quo that is difficult to overturn:

Globally less than two-thirds (62\%) of the personnel of the EPS (Private Health Establishments) are salaried, about one third (30\%) are part-time consultants and $8 \%$ are volunteers or interns. The proportion of those working part-time tends to be more significant for the most qualified categories of professionals (general practitioners and specialists). A significant number of them receive salaries from the public sector (Ministère de la Santé 2010:25).

Patients have few avenues for redress: it is almost impossible to find a doctor to act as an expert witness if a civil action is brought against a colleague. This collegial solidarity also limits the use of such sanctions as are available to the Order or to the health ministry. At best, a doctor may be relocated to a different area, where they are free to renew these practices, rather than risking their licence. A head of a hospital unit told us how he dealt with a colleague who was harming patients: 'I fired him, I blew him off, I requested his relocation... 
at first they did not do anything. And finally I asked to change the whole team, all the doctors at the same time...'

\section{CONCLUSION}

Although the medical profession in Burkina Faso have been trained in programmes that are strongly influenced by European traditions, whether in Metropolitan France or in West Africa, there is little evidence to support the idea that this has cultivated a distinctive moral character that shapes the actions of most practitioners. As Sciulli pointed out in the passage we quoted earlier, there is no reason why actors in a market should not operate in an altruistic or selfless manner. Indeed, this would be entirely consistent with Adam Smith's original understanding of the conditions for successfully functioning markets, and the place of professions within them. Self-interest is necessarily tempered by moral restraint and civic virtue, which may be symbolically rewarded, in the interests of winning the consent of all participants to the liberal social order (Winch 2009). In the bastardized version of Smith's thinking represented by the market reforms of the SAP in Burkina Faso, these elements have disappeared: self-interest is all. As such the reforms have done little to affect the manners and morals of an authoritarian state. Within this context, there are no incentives, sanctions or other pressures that would lead doctors to act in any different way from any other market provider of goods or services. To the extent that there are remnants of the historic market shelter, these can be exploited for personal gain at the expense of competitors rather than being seen as an exchange for self-restraint.

These findings contrast with Liu's (2017) account of the Chinese legal profession, possibly because of the difference between the strength of the state apparatus for controlling professional behaviour. Although both states have an authoritarian character, Burkina Faso 
lacks the institutional resources available in China to police the activities of professionals. They suggest the need to extend Liu's four positions for professions in the ecology of development: as facilitators of global institutional diffusion; as delegates of the nation-state; as brokers between global and national market institutions; and as activists of local social resistance. In Burkina Faso, we seem to be seeing professionals as classic petty entrepreneurs with little pretension to any wider role. This leads us to echo the scepticism of the Chicago School about the degree to which professional practice can be shaped by attention to the moral character of physicians rather than to the structures within which they work. This is a theme that runs through the writings of Hughes (1984) and Becker (1970) but is perhaps most obvious in Freidson's (1975) study of group practice, Doctoring Together. While this is not to dismiss the importance of education in ethics and social obligation during medical school, it is to note that these cannot be relied upon to shape practice in cultural or institutional environments that do not support these principles. 'Professionalism' conceived as an orientation to standards of work and a style of relationship with clients can only thrive in contexts that value it.

\section{Acknowledgements}

Natéwindé Sawadogo was supported by a postgraduate scholarship from the Wellcome Trust while conducting the fieldwork on which this paper is based. Unless otherwise indicated, all translations are by the authors. We are also grateful for the comments of the editors and reviewer, and for feedback from Simon Holdaway. 


\section{Endnotes}

${ }^{1}$ Very much in the Durkheimain tradition, Bourdieu associates capital with a structural model of social fields and habitus, a system of internalized dispositions. It is quite different from the interactionist tradition within which Freidson was writing, where structures were considered to be emergent from action, rather than prior, and where the idea that sociologists had access to internal mental states was, at best, problematic (Becker and Pessin 2006). Unlike Liu and Emirbayer (2016), we do not see much value in attempting to reconcile positions based on such radically different epistemologies. Bourdieu's typology of capital is adopted solely as a useful summary of dimensions that seem to be important to understanding the practical classification of occupations.

${ }^{2}$ This is a general trend in the region. As Ouédraogo notes: 'A promising approach of many governments in sub-Saharan Africa is the extension of mutual health insurance schemes to the national level. Through their integration in public social security arrangements these national schemes can exploit the potential of MHIS and reach previously excluded population segments' (Ouédraogo 2012:430).

${ }^{3}$ After the pressure from the revolutionary regime to develop traditional medicine, doctors returned to their own way of dealing with the sector, using technical and ethical argument to delay action. The Minister of Health declared: 'We are no longer subjected to the passion of the early days which made us lose sight of the complexity of the problem (traditional medicine and pharmacopoeia). The possibility of making available Galenic forms such as syrup, creams, potions etc. no longer appear as an indisputable solution of our pharmaceutical policy. We are more and more conscious of the need to surround ourselves with the maximum possible guarantees concerning the efficacy and the innocuousness of medicinal recipes from plants. The action of promoting our traditional medicine and pharmacopoeia 
should not lose sight of some of the problems of public health and medical ethics.' (Comrade Elie Sarré Secretary of State for Social Action, 11/1987).

${ }^{4}$ Decree no2016-256/PRES/PM/MINEFID/MJDHPC regarding allowance grid, bonuses and benefits of all nature allocated to judges in office and to auditors of justice, provide in its Article 11 "judicature allowance" between 524.41 to 561.87 USD to judges according to the class.

${ }^{5}$ Following traditional European practice, the Master's is a first degree in Burkina Faso. As in Europe it is now being replaced by the Bologna model of a shorter Bachelor's degree followed by further study for the Master's (normally $3+2$ years of study).

\section{References}

Abbott, A. 1988. The System of Professions. An Essay on the Division of Expert Labor. Chicago: University of Chicago Press.

Becker, H. S. 1970. Sociological Work. Chicago: Aldine.

Becker, H.S. and Pessin, A. 2006. 'Dialogue sur les notions de Monde et de Champ.' Sociologie de l'art, n.s., 8: 165-80.

Bationo, B.F.and Ouédraogo, L-M. 2012. 'Solidarity in the Extension of Micro Health Insurance -the Problem of Enrolment in Mutual Health Organisations in Burkina Faso.’ Pp. 415-427 in Rosner, H.J., Leppert, G., Degens, P. and Ouédraogo, L-M., eds. Handbook of Micro Health Insurance in Africa. Zurich: Lit Verlag.

Bloor, D. 1991. Knowledge and Social Imagery, 2nd ed. Chicago: University of Chicago Press.

Bocoum, F.Y, Kouanda, S. and Sondo, B. 2009. Les Caractéristiques des Revenus des Professionnels de la Santé et Leur Relation avec la Fourniture des Soins au Burkina Faso. Ouagadougou: Institut de Recherche en Sciences de la Santé. 
http://www.who.int/alliance-

hpsr/researchsynthesis/alliancehpsr_hwsburkinafasoreport.pdf [Accessed 10 April 2018]

Bognounou, O. and Guinko, S. 2005, Ethnobotanique-médecine Traditionnelle. Rapport, Ouagadougou: Centre National de Recherche Scientifique et Technologique.

Bourdieu, P. 1986. 'The forms of capital'. Pp. 225-39 in Richardson, J. ed. Handbook of theory and research for the sociology of education. New York: Greenwood.

Code Public \& Administratif 2. 2000. Ouagadougou: Imprimerie Presses Africaines.

Dingwall, R. 1983. “"In the beginning was the work ...” Reflections on the genesis of occupations'. Sociological Review 31; 4: 605-24.

Dingwall, R. 1995. 'Le verouillage du marché: les pharmacies anglaises dans la course à la licence 1794-1868.' Pp. 15-22 in Lasselain, J, ed. Profession Pharmacien: Le Regard des Sciences Sociales, Paris: Edition Imhotep Médecine Sciences. (English version in Dingwall, R. 2008. Essays on professions. Aldershot: Ashgate.)

Dingwall, R. 1999. 'Professions and social order in a global society.' International Review of Sociology 9; 1: 131-140.

Dingwall, R. 2006. 'The enduring relevance of professional dominance.' Knowledge, Work and Society 4; 2: 77-98.

Dingwall, R. 2016. 'The ecological metaphor in the sociology of occupations and professions.' Pp.31-48 in Liljegren, A. and Saks, M., eds. Professions and Metaphors: Understanding Professions in Society, London: Routledge.

Dingwall, R. and King, M.D. 1995. 'Herbert Spencer and the professions: occupational ecology reconsidered.' Sociological Theory 13; 1: 13-24.

Durkheim, É.1960. The Division of Labor in Society. New York: Free Press.

Durkheim, É. 1992. Professional Ethics and Civic Morals. London: Routledge. 
Freidson, E. 1970. Professional Dominance: The Social Structure of Medical Care. New York: Atherton.

Freidson, E. 1975. Doctoring Together. Chicago: University of Chicago Press.

Freidson, E. 1978. 'The Official Construction of Occupation: an Essay on the Practical Epistemology of Work', paper presented at the $9^{\text {th }}$ World Congress of Sociology, Uppsala, Sweden.

Freidson, E. 1994. Professionalism Reborn. Cambridge: Polity.

Gorman, E. H., and R. L. Sandefur. 2011. “"Golden Age,” Quiescence, and Revival: How the Sociology of Professions Became the Study of Knowledge-Based Work'. Work and Occupations 38; 3: 275-302.

Halliday, T. 1987. Beyond Monopoly: Lawyers, State Crises and Professional Empowerment. Chicago: University of Chicago Press.

Haute-Volta. 1986. Rapport Sectoriel du Plan Quinquennal de Développement Populaire 1986-1990, juin 1986

Hilgers M. and Mazzocchetti J. 2010. Révolte et Opposition dans un Régime SemiAutoritaire, le Cas du Burkina Faso. Paris: Karthala.

Hughes, E.C. 1984. The Sociological Eye: Selected Papers. New Brunswick, NJ: Transaction Books.

Johnson, T.J. 1972. Professions and Power. London: Macmillan.

Johnson, T.J. 1995. 'Governmentality and the Institutionalization of Expertise'. Pp. 7-24 in T.J. Johnson, G. V. Larkin, and M. Saks, eds. Health Professions and the State in Europe. London: Routledge.

Johnson, T.J., Larkin, G.V. and Saks, M., eds. 1995. Health Professions and the State in Europe. London: Routledge.

Kaboré, B. 2002. Histoire Politique du Burkina Faso 1919-2000. Paris: L’Harmattan. 
Kett, J.F. 1968. The Formation of the American Medical Profession: The Role of Institutions, 1780-1860. New Haven, CT: Yale University Press.

Larson, M. S. 1977. The Rise of Professionalism: A Sociological Analysis. Berkeley: University of California Press.

Light, D. 1995. 'Countervailing Powers: A Framework for Professions in Transition'. Pp. 2544 in T.J. Johnson, G. V. Larkin, and M. Saks, eds. Health Professions and the State in Europe. London: Routledge.

Liu, S. 2017. 'Overlapping Ecologies: Professions and Development in the Rise of Legal Services in China.' Sociology of Development 3; 3: 212-31.

Liu, S. and Emirbayer, M. 2016. 'Field and Ecology.' Sociological Theory 34; 1: 62-79.

Ministère de la Santé. 2006. Textes Règlementaires du Secteur de la Médecine et de la Pharmacopée Traditionnelles. Ouagadougou: Ministère de la Santé.

Ministère de la Santé. 2010. Cartographie de l'Offre de Services de Santé dans la Région du Centre. Ouagadougou: MS/DGISS.

Ministère de la Santé. 2015. Annuaire Statistique 2014. Ouagadougou: Ministère de la Santé.

Ottaway, M. 2003. Democracy challenged: the rise of semi-authoritarianism. Washington DC: Carnegie Endowment for International Peace.

Ouédraogo, J-B. 2010. 'L'émergence du Secteur Privé et les Perspectives d'avenir'. Communication Conférence Sectorielle sur La santé dans le Cadre du Cinquantenaire, Ouagadougou, Décembre 2010.

Ouédraogo, L-M. 2012. 'Access for all' and 'reaching the poor'? Integrating of mutual health insurance units into public social security arrangements-benefits and risks for mutual schemes’, Pp 429-457 in Rosner, H.J., Leppert, G., Degens, P. and Ouédraogo, L-M., eds., 2012, Handbook of Micro Health Insurance in Africa, Zurich: Lit Verlag.

Parsons, T. 1939. The professions and social structure. Social Forces 17; 4: 457-67. 
Parsons, T. 1951. The Social System. London: Routledge and Kegan Paul.

Patterson, D. 2015. Pharmacy in Senegal: Gender, Healing and Entrepreneurship

Bloomington, IN: Indiana University Press.

Politique Africaine. 2006. Le Burkina Faso: l'alternance impossible, $\mathrm{n}^{\circ}$. 101, Paris: Karthala.

Ridde, V. 2007. Equité et Mise en cuvre des Politiques de Santé au Burkina Faso. Paris:

L'Harmattan.

Rueschemeyer, D. 1983. 'Professional autonomy and the social control of expertise'. Pp. 3858 in Dingwall, R. and Lewis, P.S.C, eds. The Sociology of the Professions: Lawyers, Doctors and Others. London: Macmillan.

Rueschemeyer, D. 1986. Power and the Division of Labour. Cambridge: Polity Press.

Sarré, E. Journée portes ouvertes sur les «plantes médicinales et pharmacopées traditionnelles » Sidwaya ${ }^{\circ} 1412$ du lundi 4 décembre 1989, p.5

Sawadogo, N. 2012. Professions and the Public Interest: A Comparative Study on the Moral Division of Labour in Medical Practice in Burkina Faso. PhD thesis, University of Nottingham.

Sciulli, D. 2009. Professions in Civil Society and the State: Invariant Foundations and Consequences. Leiden: Brill.

Smith, Adam. 1976. An Inquiry into the Nature and Causes of the Wealth of Nations. Edited by Edwin Cannan. Chicago: University of Chicago Press.

Soubeiga, A. 1999 'Quête de Guérison, Conversion, Evangélisation.’ Pp. 111-128 in Otayek, R., Barbier, J.C., Diawara, M., Laurent, P.J., Monné, R., Rouamba, P. and Soubeiga, A., 1999. Dieu dans la cité (dynamiques religieuses en milieu urbain ouagalais). Bordeaux: Centre d'Etude D'Afrique Noire.

Svensson, L.G. and Evetts, J., eds. 2010. Sociology of Professions. Continental and AngloSaxon Traditions. Göteborg: Daidalos. 
Winch, D. 2009. Adam Smith's Politics: An Essay in Historiographic Revision. Cambridge: Cambridge University Press.

World Bank. 1990. World Development report 1990, Oxford, Oxford University Press

Yaya Bocoum, F., Kouanda, S., Sondo, B. 2009. Les Caractéristiques des Revenus des

Professionnels de la Santé et leur Relation avec la Fourniture des Soins au Burkina Faso. Ouagadougou: IRSS

Zagré, P. 1994. Les Politiques Économiques du Burkina Faso: Une tradition d'Ajustement Structurel, Paris: Karthala. 